\title{
Philippe Jousset, Varietas varietatis... La poétique de La Fontaine, une gaie physique de la morale
}

\section{Cecilia Torelli}

\section{(2) OpenEdition}

1 Journals

\section{Edizione digitale}

URL: https://journals.openedition.org/studifrancesi/40598

DOI: 10.4000/studifrancesi.40598

ISSN: 2421-5856

\section{Editore}

Rosenberg \& Sellier

\section{Edizione cartacea}

Data di pubblicazione: 1 juillet 2004

Paginazione: 181

ISSN: 0039-2944

\section{Notizia bibliografica digitale}

Cecilia Torelli, «Philippe Jousset, Varietas varietatis... La poétique de La Fontaine, une gaie physique de la morale», Studi Francesi [Online], 142 (XLVIII | I) | 2004, online dal 30 novembre 2015, consultato il 09 septembre 2021. URL: http://journals.openedition.org/studifrancesi/40598 ; DOI: https://doi.org/ 10.4000/studifrancesi.40598

Questo documento è stato generato automaticamente il 9 septembre 2021.

\section{(c) 9 (i) $\Theta$}

Studi Francesi è distribuita con Licenza Creative Commons Attribuzione - Non commerciale - Non opere derivate 4.0 Internazionale. 


\title{
Philippe Jousset, Varietas varietatis... La poétique de La Fontaine, une gaie physique de la morale
}

\author{
Cecilia Torelli
}

\section{NOTIZIA}

PHILIPPE JOUSSET, Varietas varietatis... La poétique de La Fontaine, une gaie physique de la morale, «XVII ${ }^{\mathrm{e}}$ siècle», n. 218, cit., pp. 71-94.

1 Tre favole di La Fontaine, La Cigale et la Fourmi, Le Lièvre et les Grenouilles, La Femme noyée, sono al centro di questo studio nel quale l'A. procede ad un'attenta analisi dei testi (nel caso specifico de La Cigale et la Fourmi l'analisi è corredata da uno schema costruito con i dati inerenti la rima, il metro e la frase) per sottolineare, senza mai dimenticare che ogni favola è avant tout une texture, la preminenza della forma sul significato e la particolarità dell'espressione di una morale che si esplicita attraverso la variazione e la diversificazione in mouvements. 